\title{
IMPACT OF APPLYING THE SUSTAINABILITY ELEMENTS ON OPERATIONAL RISK MANAGEMENT OF THE EGYPTIAN SPORTS CLUBS.
}

\author{
Alaa Sayed Mahmoud ELHalaboush ${ }^{1}$, Dr. Akram Farouk ${ }^{2}$. \\ ${ }^{1}$ Architecture Engineering Department, Faculty of Engineering, Ain Shams University, \\ Cairo, Egypt. \\ ${ }^{2}$ Architecture Engineering Department, Faculty of Engineering, Ain Shams University, \\ Cairo, Egypt. \\ *Corresponding Author E-mail: alamahmoud@msa.eun.eg, alaasayed19933@gmail.com
}

Received :21 April 2021 Accepted:1 Sept 2021

\section{ABSTRACT:}

The goal of this study is to investigate the impact of applying the sustainability elements on the construction of maintenance risk management in Egyptian sports club projects as a method of producing a sustainable and safe community. A research methodology consisting of a comprehensive literature review and a case study with three objectives. First, a detailed analysis of the literature on the principles of sustainability, operation of maintenance risk management, and sports club projects are performed. Second, present and synthesize the results of a relevant study and evaluate the impact and approve how the impact of applying the sustainability will decrease the number of risks if it is applied over the right maintenance type. Finally, draw conclusions and recommendations. The research carried out a highlighted gap in the literature with the sustainable operation of maintenance risk management. Furthermore, participants stated that a lack of practical application and the availability of successful local examples is the major reason for not applying safety and sustainability aspects. The study found 16 major effects. This paper focuses on the impacts of applying the sustainability elements on the operation of maintenance risk management in the sports clubs projects. The performed literature review and field study offered an in-depth understanding of the impact of including sustainable aspects into the operation of maintenance risk management operations as a process of delivering sustainable and safe sports club projects.

KEYWORDS: Sustainability, Operation of Maintenance Risk management, sustainable and safe sports clubs projects.

$$
\begin{aligned}
& \text { تأثير تطبيق عناصر الإستدامة على إدارة مخاطر التشغيل في الأندية الرياضية المصرية. } \\
& \text { آلاء سيد محمود الحلبوش 1, 1, دكتور أكرم فاروقئ. }
\end{aligned}
$$

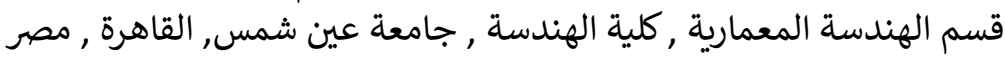

$$
\begin{aligned}
& \text { alamahmoud@msa.eun.eg, alaasayed19933@gmail.com البريد الاليكتروني للباحثة الرئيسية المية } \\
& \text { الغرض من هذه الورقة هو دراسة تأثير تطبيق عناصر الإستدامة على إدارة مخاطر التشغيل (الصيانة) في مشاريع الأندية }
\end{aligned}
$$

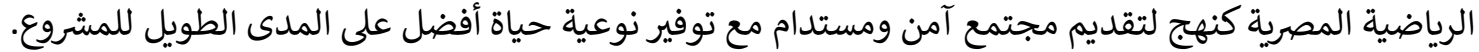

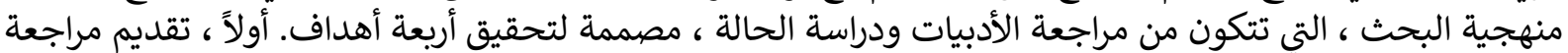

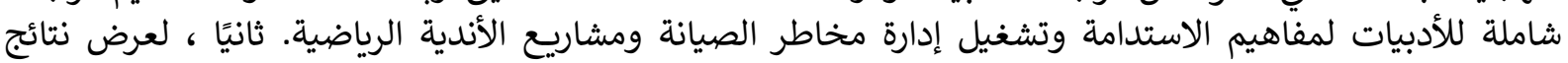

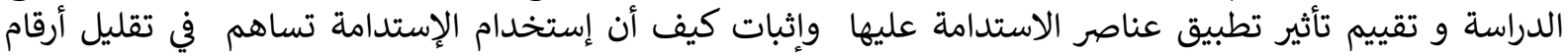



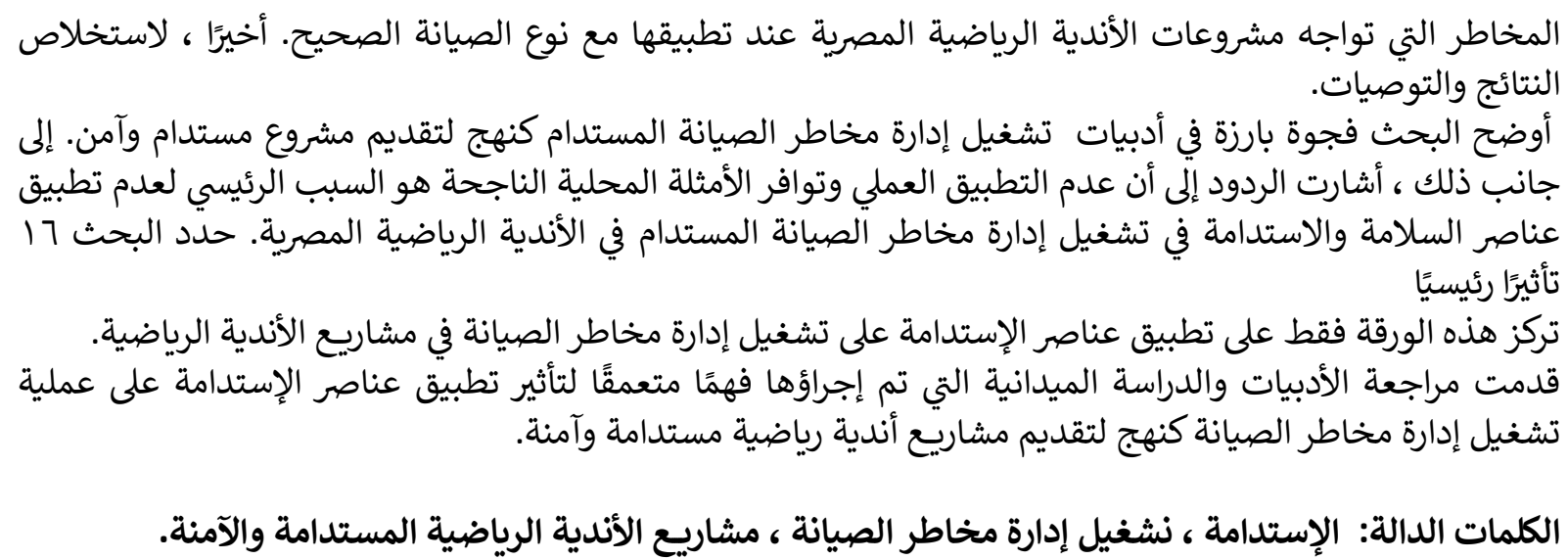

\section{INTRODUCTION}

The construction industry is essential for achieving social, environmental, and economic goals for long-term development. It is primarily concerned with delivering and achieving long-term projects that translate community needs into designs that specify technical characteristics, functional performance criteria, and quality standards. Besides, it aims to keep the project looking good and running efficiently, as well as to complete these projects on time, as specified, and as cost-effectively as possible in order to produce a product, that meets or exceeds end-user expectations. The environmental aspect of sustainability is concerned with the efficient use of natural resources, as well as the reduction of waste, pollution, effluent generation, and emissions to the environment. Furthermore, it seeks to reduce the negative impact on human health, promote the use of renewable raw materials, and eliminate toxic substances.

Economically, the construction industry contributes to a country's gross domestic product (GDP) by providing job opportunities and practices that promote long-term economic growth without negatively affecting the community's social, environmental, and cultural aspects. The unsustainable practices of construction maintenance risk management in terms of resources and energy consumption, pollution, and waste generation demanded that construction maintenance be more sustainable and take into account the environmental, social, and economic impacts on the surrounding environment.

The construction industry in general and sports club projects in particular, face more risks than any other industry due to their nature. This is related to the complex and dynamic nature of these types of construction projects, as well as the involvement of a large number of participants and organizations with varying goals and skills. The operation of maintenance risk management is a critical stage in the life cycle of any construction project. This is because decisions made during this phase have an impact on the project's performance throughout its life cycle. Failure to consider risk factors during this phase will have an impact on the project's sustainability and safety.

Although risk management (RM) is extensively utilized throughout the project life cycle, less attention has been paid to its use in the operation of the maintenance within the sustainability aspects process in building literature. (Goral, 2007; Banaitiene and Banaitis, 2012). As a result, the purpose of this paper is to identify the impact of applying, evaluating, and implementing sustainability elements into the operation of maintenance risk management as a delivery method, and having a sustainable and safe construction project for a long-term life cycle. 
However, because other researchers have not previously discussed some of the nearby research topics, it is considered innovative and unique because of three reasons. The first reason is that it is essential to Egypt's construction sector. The second reason is that it will aim to collect thorough data on the implementation and assessment of sustainability aspects in maintenance risk management operations. The third reason is to show how well executed sustainability within the right type of maintenance risk management can assist in achieving safe and sustainable development and a community of Egyptian sports clubs with the fewest risks.

\section{RESEARCH OBJECTIVES AND METHODOLOGY}

A research methodology designed to achieve four objectives:

Firstly, reviewing literature related to sustainability elements, construction of maintenance risk management, and sports clubs. Secondly, author(s), presented and synthesized the findings of a relevant study 2020, aimed to identify the impact of applying the sustainability elements over the construction of maintenance risk management of the Egyptian Al- Ahly club branches. Also, investigate the application of the sustainability elements over the construction of maintenance risk management of Egyptian sports clubs towards achieving sustainable and safe sports club projects. Thirdly, evaluate the application of the sustainability elements impact within the operation of maintenance Risk Management towards delivering sustainable and safe sports club projects. Finally, outline research conclusions and recommendations.

(1) Create a detailed understanding of the research topic by reviewing the concepts of sustainability, operation of maintenance risk management, and sports clubs project.

(2) Alaa Sayed Mahmoud, presented and synthesized the findings of a relevant study 2020, aimed to identify the impact of applying the sustainability elements over the maintenance risk management of the Egyptian Al- Ahly club branches. Also, identify the risks associated with the operation of maintenance risk management and investigate the application of the sustainability elements over the maintenance risk management of Egyptian sports clubs towards achieving sustainable and safe sports clubs' projects.

(3) Evaluate the application of the sustainability elements impact within the operation of maintenance Risk Management towards delivering sustainable and safe sports clubs projects; and

(4) Outline research conclusions and recommendations.

\section{LITERATURE REVIEW}

\subsection{Sustainability}

3.1.1. Background information and concept development, sustainability, in a wide sense, is the potential to survive. All present and future generations' requirements for life and wellbeing are directly or indirectly dependent on the natural environment. The objective of sustainability is to establish and maintain social, economic, and environmental circumstances that allow humanity to live in "productive harmony" with nature in the present and future (USEPA, 2009). Sustainability has developed into a wide word that may relate to nearly every element of life on Earth, from the local to the global, and throughout several periods. The existence of over 200 distinct definitions for sustainable development underlined its importance and demonstrated the efforts made by many academic and practical disciplines to describe and comprehend its significance in their respective fields. All definitions, however, agree that it is essential to consider the planet's future and find new methods to safeguard and improve the Earth while fulfilling the demands of diverse stakeholders (Boyko et al., 2006). 
Sustainability has defined as the integration of social, economic, and environmental spheres in order to meet the needs of the present without risking future generations' ability to meet their own needs (World Commission on Environment and Development, 1987). Furthermore, sustainability is concerned with environmental quality, social prosperity, and economic performance (Addis and Talbot, 2001). According to Maxwell (2014), to ensure the successful delivery of sustainable projects, it is necessary to integrate sustainability concepts from the beginning of any project. It is also critical to integrate sustainability elements concepts and applications with the operation of maintenance risk management to deliver a sustainable and safe project for the long-term life cycle. Sustainability has three aspects as follows:

1) The environmental aspect of sustainability, according to Othman et al. (2013), the environmental element of sustainability focuses on effectively exploiting natural resources and decreasing waste, pollution, and emissions into the environment. It also aims to decrease the negative influence on human health, encourage the use of recyclable and renewable raw resources, and remove dangerous waste.

2) A socially sustainable society a socially sustainable society is a process that entails determining what people require from the areas where they live and work in order to build long-term, effective environments that promote well-being.

3) An economically, an economically self-sustaining society is one that can fulfill the requirements of its inhabitants without relying on adjacent societies or nations for help.

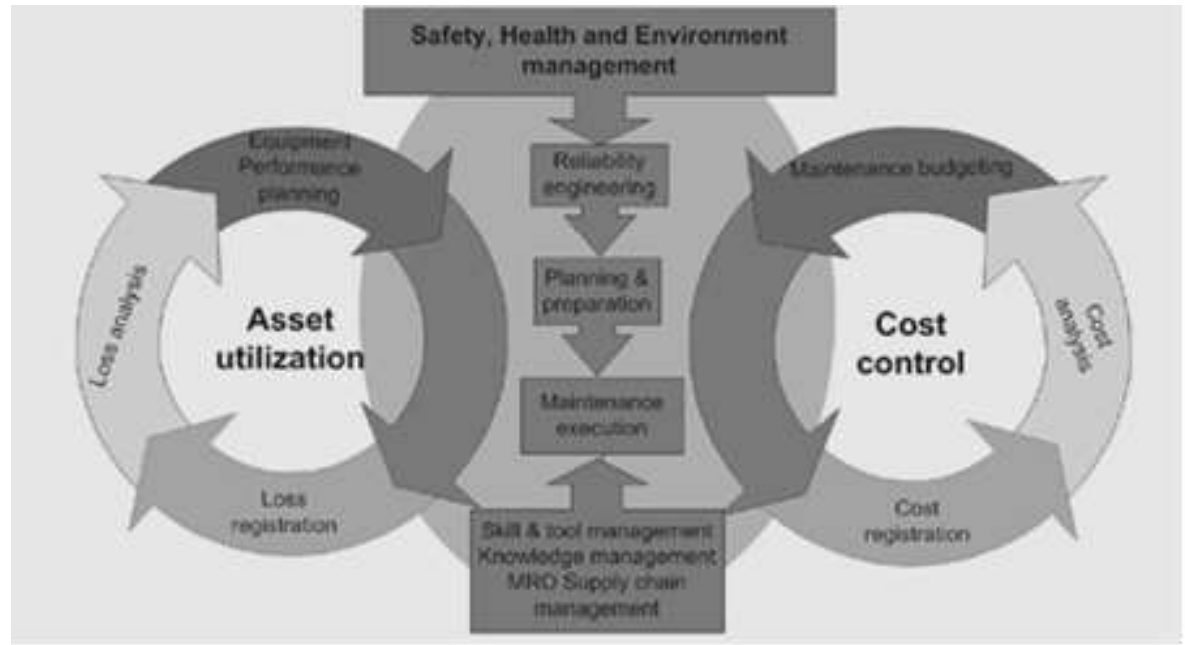

Fig. 1: Sustainability, Haarman et al, 2004

\subsubsection{Sustainability in maintenance risk management,}

Here describes the relationship between the impact of applying the sustainability elements on the operation of maintenance risk management especially and explain how both terms helping to achieve sustainability and safety,

Firstly, the term Sustainable maintenance involves the reduction of unnecessary maintenance. Unnecessary maintenance can prevent by carefully planning activities based on the actual building condition. Furthermore, sustainable maintenance methods are primarily concerned with building occupants' actions and include safety, health, comfort, and productivity, as well as a consideration of the need for future generations to reuse and recycle constructionbuilding components. 
Second, sustainable risk management (SRM) is a corporate approach that matches profit goals with organizational environmental principles. SRM (sustainable risk management) organizations often focus on the environmental effect of each business action individually and then explore strategies to minimize them. An effective sustainable risk management framework may help management detect emerging issues of concern that may affect the supply chain, operations, and production. Concerns that are emerging include the availability of renewable energy sources, the depletion of nonrenewable resources, and changes in government policies.

Finally, sustainability elements and operation of maintenance risk management are working to achieve sustainability and safety inside the projects because they have the same objective and process.

Summary, to have sustainable and safe sports club projects it is important to integrate and apply the three main different terms sustainability, construction of maintenance, and risk management.

\subsection{Operational risk management in the construction sector}

\subsubsection{Overview and its importance}

Firstly, to begin, without proper risk management and maintenance, the operation may experience unplanned downtime and expenses. Both are concentrating on preventative steps to reduce project costs and resources while ensuring that assets function optimally for the remainder of the project life cycle. In addition, it is important to apply the operation of maintenance risk management, as it is the basic stage that will reflect achieve the sustainability elements' impacts over the project. The operation of maintenance is critical to the effective delivery and continuance of any project. It is intended to be a key process since it involves the most significant choices that affect project performance throughout its life cycle. For instance, decisions about end-user engagement, cost estimation, material selection, system kinds, and observation control systems are essential and can affect the project's outcome favorably if well managed or adversely if disregarded. Facilities maintenance is the typically financed continuing program for the maintenance and preservation of buildings, equipment, roadways, grounds, and utilities necessary to keep a Facility in good working order. Each style and type of applied maintenance accomplishes and reflects sustainability aspects with varying impact, and vice versa, by author, 2021.

Maintenance has many types according to Dhillon, encompasses both planned, preventative, and emergency actions, as well as unexpected or reactive actions Maintenance required the provision of a safe, sustainable, healthy, and secure environment. Each sort of maintenance operation makes use of several software functions to fulfill its tasks. Furthermore, the sustainability factor applications influence differently depending on the type of maintenance used. Maintenance is necessary not just to maintain reliability, but also to minimize operating costs during the life of the system and to prevent accidents. As a result, the proper application of maintenance is performed to enhance sustainability and safety, as improper maintenance performances might result in significant losses. (Holmgren, 2005). In addition, when maintenance needs to occur due to an external event, an event trigger may be used. 


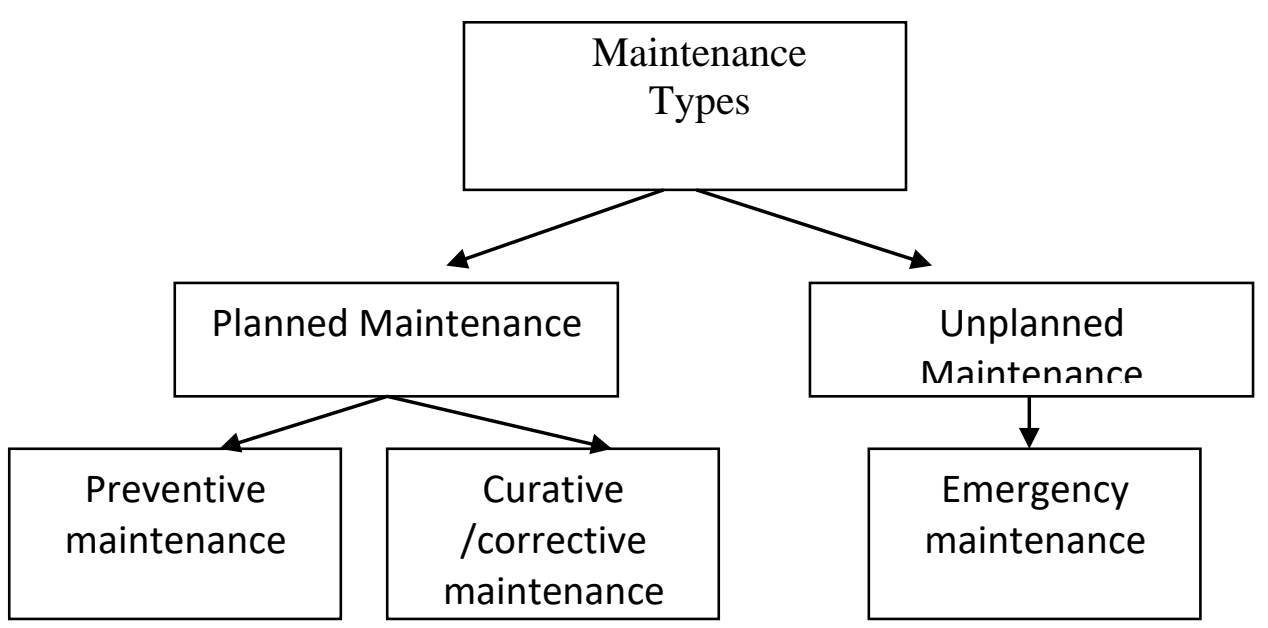

Fig. 2: the modern concept of maintenance classification

Table 1: the modern concept of maintenance types definitions.

\begin{tabular}{|c|c|}
\hline $\begin{array}{r}\text { Pla } \\
\text { Maint }\end{array}$ & $\begin{array}{l}\text { The care of property, machinery, and infrastructure such } \\
\text { as buildings, utility systems, roads, and grounds is known } \\
\text { as planned maintenance, sometimes known as } \\
\text { "programmed" or "scheduled" maintenance. A kind of } \\
\text { scheduled maintenance is routine or recurrent } \\
\text { maintenance. The mission employs planned and } \\
\text { scheduled maintenance rather than unplanned/reactive } \\
\text { maintenance. }\end{array}$ \\
\hline $\begin{array}{l}\text { Prev } \\
\text { Main }\end{array}$ & $\begin{array}{l}\text { Maintenance based on proper planning aims to prevent } \\
\text { unplanned stops Equipment that by setting a specific } \\
\text { program to periodically performs cleaning and servicing. } \\
\text { All equipment, tools, and machines inside the club, and } \\
\text { their examination, inspection, and replacement Corroded } \\
\text { parts of it with other new parts, and if it occurs after that, } \\
\text { it stops or fails It conducts a careful investigation to find } \\
\text { out its cause and maintains statistical records to help } \\
\text { (Learn about the effectiveness of the program put in } \\
\text { place). }\end{array}$ \\
\hline $\begin{array}{l}\text { Unp } \\
\text { Main }\end{array}$ & $\begin{array}{l}\text { Determine what reactive or unanticipated activities must } \\
\text { be completed immediately to avoid breakdowns. Serious } \\
\text { risks include lost productivity, significant asset damage, } \\
\text { worker safety, and, in most cases, dealing with } \\
\text { disruptions that generate the essential needs to carry out } \\
\text { since they are not expected to occur (Malfunctions). }\end{array}$ \\
\hline $\begin{array}{c}\text { Emergency } \\
\text { Maintenance }\end{array}$ & $\begin{array}{l}\text { Emergency maintenance is described as the repair or } \\
\text { replacement of Facility components and equipment that } \\
\text { require immediate attention because the functioning of a } \\
\text { critical system is affected or human health, safety, or } \\
\text { security is threatened. Emergency maintenance takes } \\
\text { precedence over all other forms of maintenance. }\end{array}$ \\
\hline
\end{tabular}




\begin{tabular}{|c|c|}
\hline $\begin{array}{c}\text { Corrective } \\
\text { maintenance }\end{array}$ & $\begin{array}{l}\text { Corrective maintenance is done after a failure has } \\
\text { occurred. In addition, it aims to promptly correct a } \\
\text { specific failure or defect in a part of the machine his } \\
\text { appearance to ensure that the machine restarted after it } \\
\text { has stopped or returned to work at the required rate if the } \\
\text { failure or defect resulted in a reduction in its production } \\
\text { capacity or the quality of its performance. }\end{array}$ \\
\hline
\end{tabular}

Table 2: classification of maintenance type based on maintenance triggers.

\begin{tabular}{|l|l|l|}
\hline No. & $\begin{array}{l}\text { Maintenance } \\
\text { trigger }\end{array}$ & Maintenance type \\
\hline 1. & Breakdown & Run to failure, corrective and preventive. \\
\hline 2. & Usage & Preventive, condition based, and Predictive. \\
\hline 3. & Condition & Condition based and Predictive. \\
\hline 4. & Time & Preventive Condition based and Predictive. \\
\hline 5. & Event & Preventive Condition based and Predictive. \\
\hline
\end{tabular}

Summary, the operation of maintenance plays a critical part in the system's sustainability and safety because when there is no breakdown or just a minor breakdown, the system's sustainability and dependability are ensured. As a result, sustainable risk assessment and maintenance work must be linked in order to be more proactive or smart in order to maintain the system life cycle process.

Secondly, risk management because of the dynamic nature of any sort of project, especially sports club projects, different constructions, activities, organizations, and facilities with varying aims and abilities are involved. Every project is vulnerable to several sorts of risks that might endanger its completion. These risks may result in project failure, client discontent, expense overruns, and so on. According to Raftery (1994), risk is defined as the exposure to the possibility of economic or financial loss or gain, physical danger or harm, or delay because of the uncertainty involved with following a specific course of action described as a risk. Risk management processes are:

\section{1) Risk Identification.}

Risk identification is an investigation process for all risks that may arise over the course of a project and have an impact on its completion. Implementing this approach early in the project life cycle makes the client and stakeholders aware of the related risks and allows them to control them voluntarily. Winch 2002 stated that the initial stage in the risk management process is generally an informal step based on old experiences in detecting potential risks Identifying potential risks is a responsibility performed by the organization, regardless of how these risks are allocated. It is critical to emphasize that RM (risk management) is about more than just responding to hazards; it is also about being well prepared for prospective dangers that may arise unexpectedly. For risk identification, a variety of approaches are commonly 
used, including brainstorming, interviews, surveys, consulting experts, the Delphi methodology, historical data, and checklists (Smith et al., 2006; Lester, 2007; PMI, 2013).

\section{2) Risk Analysis.}

Risk analysis was performed for both individual and cumulative risks. It assists the client and project stakeholders in developing their own future vision for the probability and consequence of risk occurrence, which supports decision-making. A typical project risk assessment may be accomplished using a variety of approaches. The appropriate technique is determined by several variables, including the kind of risk, project scope, method cost, flexibility, complexity, completeness, usability, validity, and credibility (Lichtenstein, 1996). Risks can be quantified and/or qualitatively analyzed. To begin, quantitative risk analysis required the entry of numerical data as well as the execution of specific equations. Quantitative approaches, such as Monte Carlo simulation and sensitivity analysis, which require a significant amount of time and effort, are not required for all projects. Small projects may not need to go through all of the phases of quantitative analysis, but medium to big projects do. Second, qualitative risk analysis is based on the team's experience to estimate risk probability and severity.

\section{3) Risk Response.}

Based on the results of the previous two steps, there are three alternative actions:

(1) Risk Avoidance or Reduction: Identifying risks early on enables the project client and stakeholders to identify risk avoidance or reduction measures such as redesign or extra research for alternative solutions.

(2) Risk Transfer: It allows for the transfer of risk from one party to another based on the party's ability to cope with risk while maintaining the overall level of risk specified in the contract.

(3) Risk Retention: Retaining the risk may be the only choice in some situations (Ehsan et al., 2010).

Summary, risk management is an essential subject in connection to an organization's sustainability, safety, and financial integrity, and risk assessment is an important part of the maintenance strategic development. An organization's risk management approach should aim to identify, analyse, monitor, and manage all of the risks it confronts in order to keep them below a specific limit, accepted by the entity's management. 


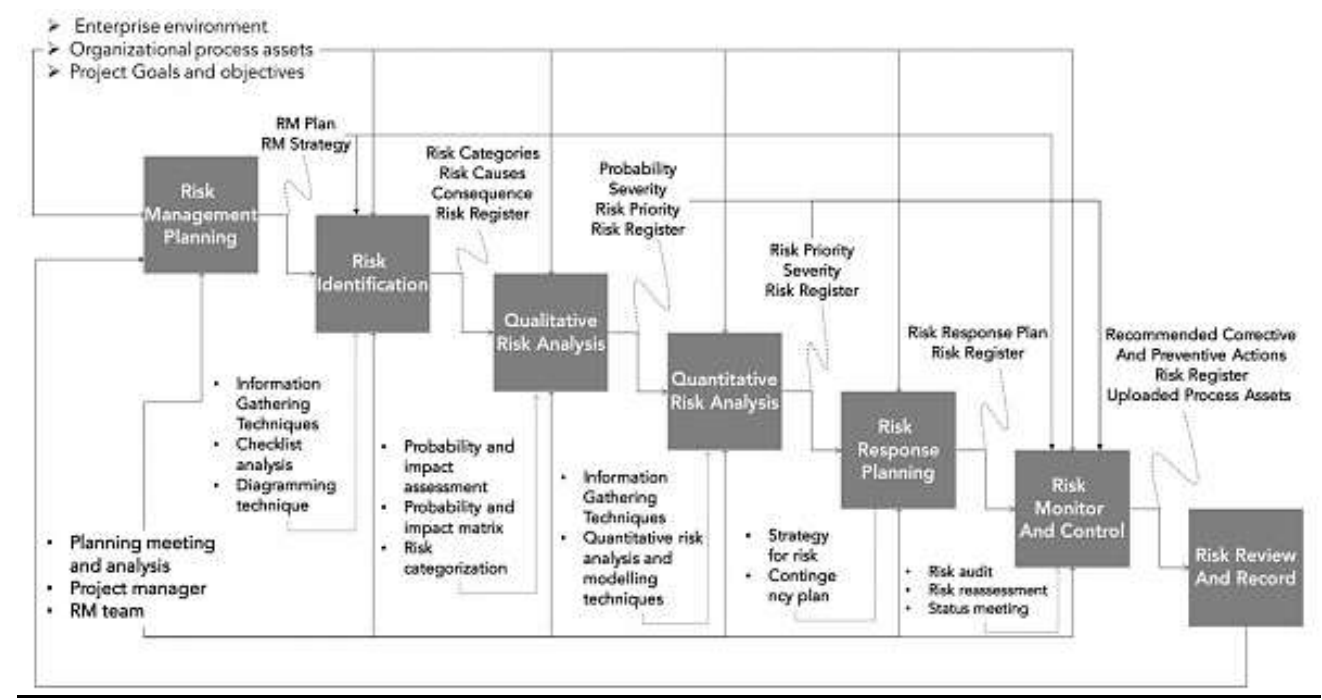

Fig. 3: Risk Management Process (PMBOK, 2008).

\subsubsection{Sustainability and operation of maintenance risk management}

Sustainability and operation of maintenance risk management in any sports club's project are very important in such kind of project due to the risks that faced this kind of project. Besides, a good sustainability and maintenance management system makes equipment and facilities available Availability indicate that the production team may request and get any item, such as light, power, air, gas, heating, cooling, or machine tools, whenever they are required. Time and money are wasted if the needed equipment or service is unavailable, or if the machine fails to complete a task. A strong sustainability and maintenance management system support achieving minimal downtime while using the fewest resources (Kishan, 2006). Failure to evaluate risk concerns during this phase will have an impact on the project's sustainability and safety.

A risk-based sustainable maintenance strategy based on three main phases:

1. Identifying and assessing risks.

2. Risk-based maintenance planning

3. A strategy for long-term development based on the risk of applicable maintenance operations.

Summary, the importance of the sustainable operation of maintenance risk management appeared in providing a comprehensive and structured approach to analysing risks during the life cycle of the Project. Without proper risk management and sustainability planning, businesses may experience unexpected downtime and expenses. The approach of this paper is to figure out the impacts of applying the sustainability elements above the operation of maintenance risk management in the exiting sports clubs projects in order to get a sustainable and safe project. Also, minimize costs, resources, and ensure that the project type achieves maximum performance during the span of their life cycle (Lewis and Payant, 2007).

As a societal consequence, system downtime has an effect on the number of items produced per cycle time and the delivery time. When there is a significant level of production disruption, the cost of maintenance for unstable systems appears to be considerable. The case for optimizing the chain connecting production activities with maintenance must be 
consistent, available, and long-term. To ensure that the entire system retains its original state, obstacles of high-risk uncertainties must remove. Three elements must be considered for the system to be sustainable: cost (economic), social effect, and environmental impact (John 2015). When the cost of maintenance is high, the cost of manufacturing rises, affecting enduser demand and therefore the social aspect. When a risk tool has adjusted to a smart level, it optimizes maintenance operations and decreases the amount of time spent on maintenance tasks as well as the cost invested.

According to Kishan (2006), the fundamental processes of risk management are the following: request, approval plan, scheduling, conducting work, capturing data, accounting for expenses, generating management information, updating equipment history, and giving management control reports. Elements of effective sustainable maintenance risk management include:

-Sustainability Control System

-Maintenance Control System

-Material Management

-Work Order System

-Equipment Reports

-Preventive and Corrective Maintenance

-Planning and Scheduling

-Backlog Management and Priority System

-Performance Measurement over the sustainability of maintenance risk management.

\subsection{Sports Clubs' Project}

\subsubsection{Definition and background}

Sports clubs refer to several buildings and open spaces in an enclosure, having a shared or associated purpose. Some found it as a standalone and some found integrated within different projects. Sports clubs considered small communities where different facilities provided. (Invest in Egypt, 2013). Location, is one of the most critical factors for selecting any sports club but now this concept became wider, and selecting sports clubs developed to take into consideration several criteria such as, the true community that provides opportunities for playing, gathering, meetings, and making contact with different people at many levels, as well as, safety, security, and comfort. Additionally, make life easier, easy to drive, to park, and to stay in for a long time. In addition, of that, sports clubs projects already became a new popular investment spot now. Sports Club Projects have already become a new attractive investment location. The investment in Sports Club projects had the characteristics of a fantastic investment, a lengthy time of return, a high degree of risk, and a large reward. As a result, before investing in a project, investors must conduct rational forecast and scientific appraisal of the project's risk, to assure the participation investment return (Fei \& De-huang, 2005).

\subsubsection{Current trends of Sports Clubs}

According to Mahmoud EL Zahwey, "Sports never fails to provide its fans with an ultimate vent to let go of their worries and stresses". This has led to the evolvement of sports 
investment culture worldwide and has consequently translated into facts, demonstrating the expansion of the international sports industry all along, especially in the past few years.

Residential and commercial projects might be taking the lion's share of urban development planning in Egypt. However, recent trends have indicated that the establishment of recreational and sports facilities all around the North African country is progressing at an unprecedented pace, with both public and private players making significant strides in this sector. Besides, according to the voice of the real estate market making waves in the global and local economic sphere, the sports industry has just started to act as an alluring opportunity for some investors worldwide. For Egypt, although developers see that implementing standalone sports projects is a worthy investment for various reasons, incorporating such types of amenities in the master plan of their integrated projects has recently become a more worthy common approach. Even if these sports developments do not stand lucrative by themselves, they add up to the package of services that developers offer to their clients when selling a housing unit.

According to the above unique features of the sports clubs' projects, the need to create sustainable, safe, and healthy environments for sporting users/employees increased (Fiyozat, 2003, Singh, 2006, Zivdar Z \& Zivdar B. 2014). The operation of maintenance and sustainable risk procedures should reinforce and practiced whenever possible. If there is a need to adopt a specific sustainable safety code, then its benefit should explain and people always reminded of its importance. Facilities and equipment that are well maintained and managed are some of the best public consumer relations tools.

\subsubsection{Sustainable and safe Sports Clubs}

It is important to apply the sustainable operation of the maintenance risk management in the sports clubs projects because it plays a major role to control and protect all the facilities, equipment, furniture, different buildings, and its staff in addition to the pavements, track, playgrounds, and the entertainment zones. Most sports clubs have numerous facilities, which include areas built or maintained to allow people to participate in sport and recreation activities, such as a pool, various playgrounds, a gym, or an oval, as well as any structures that support people involved in sport and recreation, such as a change room, canteen, grandstand, or scoreboard.

Besides that, these kinds of projects have many facilities so the need to apply and implement the sustainable safety requirements will be greater in order to protect the users/staff and create a sustainable and safe environment (maximizing their facility's use and operating in an efficient, safe, and equitable manner). Additionally, according to maintenance standards, it is important if you want to minimize injuries to athletes, staff, and users because of improperly applied/poorly maintained equipment. A sports facility manager, maintenance engineers, and project managers managed/maintained sport and recreation facilities. Capital and operational management, leasing, building, planning, designing, and marketing are all part of the job. To ensure that operations operate effectively, management must coordinate not just the facility but also its workers. Furthermore, a sports equipment manager should be in charge of the procurement, maintenance, and disposal of sports equipment for their organization. They also make certain that every piece of equipment satisfies functional and players use safety standards before it. Meeting these requirements is important if you want to avoid athlete injuries caused by inadequate equipment maintenance. 
In addition, it is important to think about many aspects: the available resources, building and using materials of the sports clubs, minimize the use of water, the use of electricity, and design and create places according to the people's needs. Therefore, it is important to consider and apply the sustainability elements within the operation of maintenance risk management to achieve sustainability and safety within the project.

\subsection{Review of relevant field studies}

This section summarizes the findings of recent research done by the researcher Alaa Sayed Mahmoud (2020). The study focused on figuring out the impact of applying the sustainability elements on construction risk management(construction maintenance risk management) in some selective Egyptian sports clubs and figuring out if the sustainability exists or not and what are the sustainability elements applied and if it applied within the construction maintenance risk management what are their impacts. Besides, explain which types of maintenance risk management are used: scheduled, unscheduled, or emergency. In addition, comparing the results to the ideal solution and figuring out the users/staff satisfaction of the club maintenance.

The research carried out a highlighted gap in the literature with the sustainable operation of construction of maintenance risk management as a method for creating sustainable and safe projects. Besides, answers showed that the lack of practical application and availability of effective local examples is the primary factor for not using sustainable aspects in construction maintenance risk management in Egyptian sports clubs. This brings up an important point about the difference between the theoretical and practical parts of sustainability. Furthermore, respondents said that including sustainable concepts in the construction of maintenance risk management is not a required requirement imposed by clients or the government. Furthermore, respondents said that a lack of senior management persuasion of the benefits of including sustainability in the construction of maintenance risk management is a barrier to its acceptance and execution. Finally, respondents stated that the dominant culture in the construction industry in terms of reluctance to change and adopt new approaches, as well as inadequate support for training programs and a lack of resources available, are other factors impeding the adoption of maintenance risk management as an approach to delivering sustainable and safe construction sports clubs projects.

\section{RESULTS AND DISCUSSION}

According to a study done by the author 2020, in the Egyptian sporting club (al-ahly club) the research methodology was used (data collection, Sampling with sample size, data presentation, and data analysis).

Firstly, Data Collection, the data collection is composed of a literature review, and interview questionnaire.

Literature review intensive literature review was conducted to understand details about sustainability elements, construction of maintenance risk management, and sports clubs.

Interview Questionnaire to gather data about the impact of applying the sustainability elements on the construction of maintenance risk management in Al ahly club (an open-ended and closed type of collective questionnaire was developed). 
The Interview Questionnaire has five parts that cover the following topics (scale licker scales used and open-ended questions).

Section I- General Information

Section II- Sustainability Elements

Section III - Construction of Maintenance Risk Management

Section IV- The impacts of applying the sustainability elements on construction of maintenance risk management

Section V - Users satisfaction (Users satisfaction of AL Ahly Club Staff/Members)

Interview the semi-structured interview followed to collect necessary information from many departments and people: sustainability engineers, managerial (project managers), maintenance engineers, observation team, CEO, members', and training coordinator has been interviewed.

Secondly, Sampling with sample size, Sample size there are total of 68 employees/users under the sustainability, maintenance, management department team, observation team, and users. All participated in data collection. 20 sustainability, risk management and maintenance department employees participated to get more or less a full understanding of employees and construction history. In addition to buildings operators and technical staff to understand the impact of sustainability on quality, 8 staff from the observation team quality control and assurance department selected 40 users from members with different age criteria. The total number of participants with their position will be as presented in Table 3: and this applied in al ahly club over all the existing branches:

Table 3: Participants for data collection with their respective positional ahly club, by the author (2020).

\begin{tabular}{|c|c|c|c|}
\hline $\mathrm{NO}$ & Department & Position & Quantity \\
\hline \multirow[t]{6}{*}{1.} & \multirow[t]{6}{*}{$\begin{array}{l}\text { Sustainability and Maintenance } \\
\text { risk management and Engineering } \\
\text { team department. }\end{array}$} & $\begin{array}{l}\text { Sustainability and Maintenance risk } \\
\text { management and Engineering team } \\
\text { department manager }\end{array}$ & 01 \\
\hline & & $\begin{array}{l}\text { Supervisors (Sustainability and } \\
\text { construction of maintenance risk } \\
\text { management supervisor, utility } \\
\text { supervisor, and workshop supervisor) }\end{array}$ & 02 \\
\hline & & $\begin{array}{l}\text { Mechanics (Operator mechanic, } \\
\text { mechanic, senior mechanic) }\end{array}$ & 06 \\
\hline & & $\begin{array}{l}\text { Electrician (Junior electrician, senior } \\
\text { electrician) }\end{array}$ & 06 \\
\hline & & $\begin{array}{l}\text { Workshop staffs (machinist and } \\
\text { winder) }\end{array}$ & 03 \\
\hline & & Experts & 02 \\
\hline & Total Number & & 20 \\
\hline \multirow[t]{2}{*}{2.} & \multirow[t]{2}{*}{ Users (Staff/Members) } & Over 20 & 10 \\
\hline & & Over 25 & 10 \\
\hline
\end{tabular}




\begin{tabular}{|l|l|l|l|}
\hline & & Over 30 & 10 \\
\cline { 3 - 4 } & Total Number & Over 50 & 10 \\
\hline 3. & $\begin{array}{l}\text { Quality Control and Quality } \\
\text { Assurance Department }\end{array}$ & $\begin{array}{l}\text { Supervisor (Quality Control } \\
\text { Supervisor, Quality Assurance } \\
\text { supervisor). }\end{array}$ & 40 \\
\cline { 3 - 4 } & staff & 02 \\
\hline & & 8 \\
\hline \multicolumn{2}{l}{ The total number of employees } & 68 \\
\hline
\end{tabular}

Thirdly, data presentation and data analysis, according to the comprehensive literature study and a field study to Al-Ahly club with its branches, questionnaire, and interview have done by the author found that results from the surveys could be showing and summarized as:

First starting with the survey analysis and second with the study analysis. Results and analysis shown on tables and figures.

The survey analysis,

1/ There is an impact from the applied sustainability elements over the operation of maintenance risk management and an impact of the operation of maintenance risks type on the applied sustainability elements over the chosen sports club.

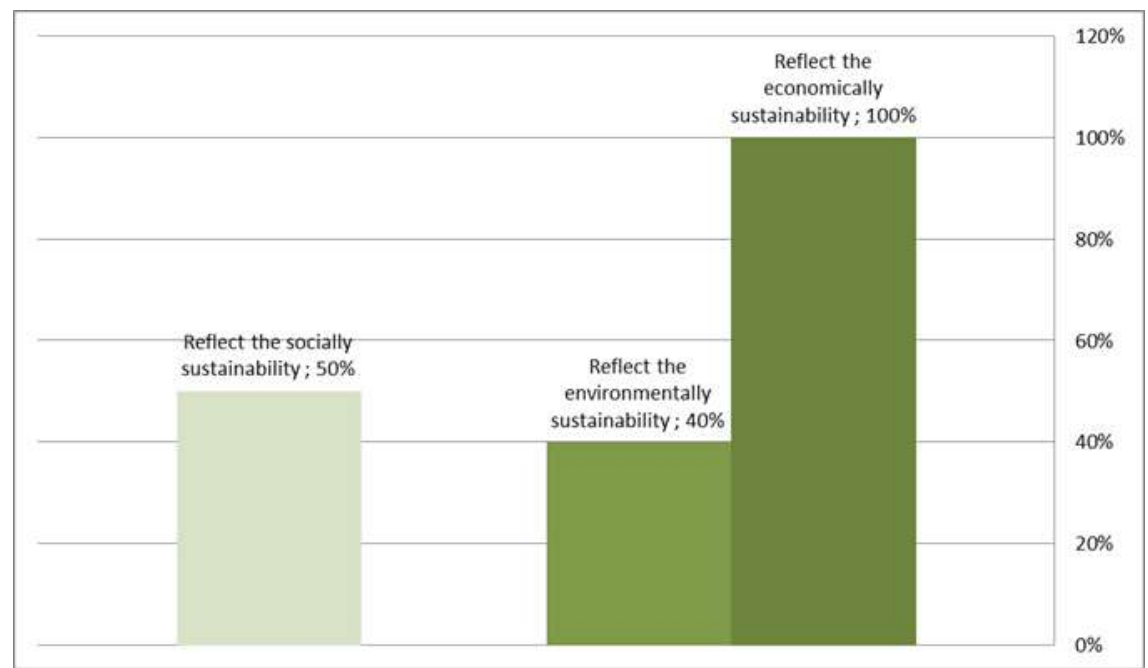

Fig. 4: Showing the impacts of the operation of maintenance risks on sustainability, by author, (2020)

Knowing that from the survey, it is only $20 \%$ the impact of the sustainability elements over the applied preventative of maintenance risk management while $80 \%$ the impact of the applied sustainability over the emergency maintenance risk management. 


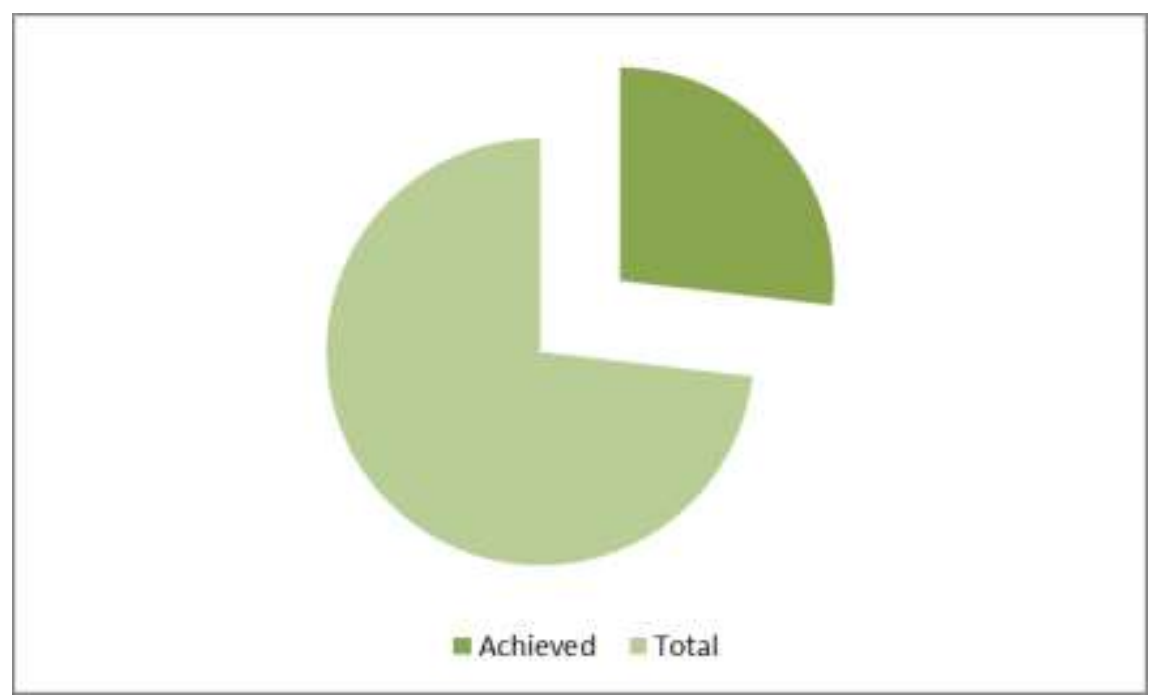

Fig. 5: Showing the ratio of the applied sustainability elements above the existing operation of maintenance risk management on the selected clubs, by author, 2020

Besides, the study showed that the sustainability impact increase and decreased depending on the operation of maintenance risk management that applied in the selected sports clubs. The impact will be poor effective (the sustainability elements impact will be not much effective) if using an inappropriate type of operation of maintenance risk management, while if using the appropriate construction of maintenance risk management it will be much planned so the impact of the sustainability elements will be effective and increased. Therefore, it will increase the safety within the sustainability.

Also, according to Schneider, "a good maintenance risk management enables high positive impacts of the sustainability elements inside any place" and according to research done by IPMI stated that: "The preventative maintenance construction risk management its original sustainability". Furthermore, the proper selection of sustainability elements and the appropriate construction of maintenance risk management methods will reduce the likelihood of failures in the production system and their implications for sustainability, safety, economics, and the environment.

Table 4: Showing the impact of the sustainability elements within different aspects in the selected sports club when chosen the appropriate maintenance and sustainability, by author, (2020)

\begin{tabular}{|c|l|l|l|}
\hline Impact & \multicolumn{1}{|c|}{ Economic Impact } & Environmental Impact & \multicolumn{1}{c|}{ Social Impact } \\
\hline & $\begin{array}{l}\text { EEvironmental expenses } \\
\text { are kept under control. } \\
\bullet \text { Material supply is under } \\
\text { control. }\end{array}$ & $\begin{array}{l}\square \text { Controlled the amount } \\
\text { of waste generated } \\
\square \text { Controlled the energy } \\
\text { consumption } \\
\text { per unit. } \\
\text { •Assist in reducing } \\
\text { materials and resources } \\
\text { by implementing the } \\
\text { proper maintenance } \\
\text { strategy control system. }\end{array}$ & $\begin{array}{l}\square \text { Controlled and improve } \\
\text { the safety, operators and } \\
\text { technical personnel } \\
\text { practices. } \\
\square \text { reduce the possible } \\
\text { resources consumption. } \\
\text { number of accidents at } \\
\text { work and execution. } \\
\square \text { Increasing the } \\
\text { sustainable social spaces }\end{array}$ \\
\hline
\end{tabular}




\section{The study analysis,}

2/ In table 5, showing the impacts of the sustainability elements that applied over the existing operation of maintenance risk management on al ahly clubs summarized and showed as:

\section{-Total Cost}

-Availability of the resources

-Availability of tools

-Availability of workers

-Applied new technologies

-General buildings performance

-Water consumption

-Electricity Consumption

-Social sustainable spaces

-The type of applied maintenance

Table 5: Showing the impact of applying the sustainability elements over the existing operation of maintenance risk management of the selected club, by author 2020

\begin{tabular}{|c|c|c|c|}
\hline $\begin{array}{l}\text { The sustainability } \\
\text { impacts over the } \\
\text { existing operation } \\
\text { of maintenance } \\
\text { risk management }\end{array}$ & $\begin{array}{l}\text { Al- Ahly Club } \\
\text { Gezira Branch }\end{array}$ & $\begin{array}{l}\text { Al- Ahly Club } \\
\text { Al Sheikh Zayed } \\
\text { Branch }\end{array}$ & $\begin{array}{l}\text { Al- Ahly Club } \\
\text { Nasr City Branch }\end{array}$ \\
\hline Total Cost & $\begin{array}{l}\text { Decreased by } 60 \% \text { of } \\
\text { the total cost }\end{array}$ & $\begin{array}{l}40 \text { percent of the } \\
\text { overall cost decreased. }\end{array}$ & $\begin{array}{l}40 \text { percent of the } \\
\text { overall cost decreased. }\end{array}$ \\
\hline $\begin{array}{l}\text { Availability of } \\
\text { resources }\end{array}$ & $\begin{array}{l}\text {-Reducing the amount } \\
\text { of material used } \\
\text { during maintenance } \\
\text { activities. } \\
\text {-Increase the } \\
\text { Availability with a } \\
\text { minimum number of } \\
\text { costs. } \\
\text {-Encouraging using } \\
\text { the recycling materials } \\
\text { (reuse materials) }\end{array}$ & $\begin{array}{l}\text {-Reducing the amount } \\
\text { of material used during } \\
\text { maintenance activities. } \\
\text {-Increase the } \\
\text { Availability with a } \\
\text { minimum number of } \\
\text { costs. } \\
\text { - Encouraging using } \\
\text { the recycling materials } \\
\text { (reuse materials) }\end{array}$ & $\begin{array}{l}\text {-Reducing the amount } \\
\text { of material used during } \\
\text { maintenance activities. } \\
\text {-Increase the } \\
\text { Availability with a } \\
\text { minimum number of } \\
\text { costs. } \\
\text { - Encouraging using } \\
\text { the recycling materials } \\
\text { (reuse materials) }\end{array}$ \\
\hline $\begin{array}{l}\text { Availability of the } \\
\text { tools }\end{array}$ & $\begin{array}{l}\text {-Increase the } \\
\text { Availability with a } \\
\text { minimum number of } \\
\text { costs. } \\
\text {-Maintain the existing } \\
\text { tools continuously to } \\
\text { extend the life span } \\
\text { also rebuilt tools using } \\
\text { recycling materials. } \\
\text {-Control of } \\
\text { manufacturing } \\
\text { equipment to reduce } \\
\text { waste. }\end{array}$ & $\begin{array}{l}\text {-Increase the } \\
\text { Availability with a } \\
\text { minimum number of } \\
\text { costs. } \\
\text {-Maintain the existing } \\
\text { tools continuously to } \\
\text { extend the life span } \\
\text { also rebuilt tools using } \\
\text { recycling materials. } \\
\text {-Control of } \\
\text { manufacturing } \\
\text { equipment to reduce } \\
\text { waste. }\end{array}$ & $\begin{array}{l}\text {-Increase the } \\
\text { Availability with a } \\
\text { minimum number of } \\
\text { costs. } \\
\text {-Maintain the existing } \\
\text { tools continuously to } \\
\text { extend the life span } \\
\text { also rebuilt tools using } \\
\text { recycling materials. } \\
\text {-Control of } \\
\text { manufacturing } \\
\text { equipment to reduce } \\
\text { waste. }\end{array}$ \\
\hline $\begin{array}{l}\text { Availability of } \\
\text { workers }\end{array}$ & $\begin{array}{l}\text {-Training the } \\
\text { employees involved in }\end{array}$ & $\begin{array}{l}\text {-Training the } \\
\text { employees involved in }\end{array}$ & $\begin{array}{l}\text {-Training the } \\
\text { employees involved in }\end{array}$ \\
\hline
\end{tabular}




\begin{tabular}{|c|c|c|c|}
\hline & $\begin{array}{l}\text { maintenance. } \\
\text { Decrease the needs to } \\
\text { recruit new workers } \\
\text { by doing training for } \\
\text { the existing } \\
\text { employees. }\end{array}$ & $\begin{array}{l}\text { maintenance. Decrease } \\
\text { the needs to recruit } \\
\text { new workers by doing } \\
\text { training for the } \\
\text { existing employees. }\end{array}$ & $\begin{array}{l}\text { maintenance. Decrease } \\
\text { the needs to recruit } \\
\text { new workers by doing } \\
\text { training for the } \\
\text { existing employees. }\end{array}$ \\
\hline $\begin{array}{l}\text { Applied new } \\
\text { technologies }\end{array}$ & $\begin{array}{l}\text { New systems } \\
\text { implemented, leading } \\
\text { to higher quality of } \\
\text { life at a lower cost. }\end{array}$ & $\begin{array}{l}\text { New systems } \\
\text { implemented, leading } \\
\text { to higher quality of life } \\
\text { at a lower cost. }\end{array}$ & $\begin{array}{l}\text { New systems } \\
\text { implemented, leading } \\
\text { to higher quality of life } \\
\text { at a lower cost. }\end{array}$ \\
\hline $\begin{array}{l}\text { General buildings } \\
\text { performance }\end{array}$ & $\begin{array}{l}\text { When compared to } \\
\text { normal buildings, } \\
\text { these buildings save } \\
\text { energy, water, cost } \\
\text { less to operate, create } \\
\text { less waste, and have } \\
\text { more pleased users. }\end{array}$ & $\begin{array}{l}\text { When compared to } \\
\text { normal buildings, } \\
\text { these buildings save } \\
\text { energy, water, cost less } \\
\text { to operate, create less } \\
\text { waste, and have more } \\
\text { pleased users. }\end{array}$ & $\begin{array}{l}\text { When compared to } \\
\text { normal buildings, } \\
\text { these buildings save } \\
\text { energy, water, cost less } \\
\text { to operate, create less } \\
\text { waste, and have more } \\
\text { pleased users. }\end{array}$ \\
\hline Water consumption & $\begin{array}{l}\text { Applied new } \\
\text { technology and } \\
\text { decreased total } \\
\text { consumption. Also, } \\
\text { depending more to } \\
\text { create wells }\end{array}$ & $\begin{array}{l}\text { Applied new } \\
\text { technology and } \\
\text { decreased total } \\
\text { consumption. }\end{array}$ & $\begin{array}{l}\text { Applied new } \\
\text { technology and } \\
\text { decreased total } \\
\text { consumption. }\end{array}$ \\
\hline $\begin{array}{l}\text { Electricity } \\
\text { Consumption }\end{array}$ & $\begin{array}{l}\text { Applied new } \\
\text { technology and } \\
\text { decreased } \\
\text { consumption. Also } \\
\text { depending on } \\
\text { aumento, application } \\
\text { that has cables plan- } \\
\text { controlling system } \\
\text { with an alarm to notify } \\
\text { the problem. }\end{array}$ & $\begin{array}{l}\text { Applied new } \\
\text { technology and } \\
\text { decreased } \\
\text { consumption. Also } \\
\text { depending on } \\
\text { aumento, application } \\
\text { that has cables plan- } \\
\text { controlling system } \\
\text { with an alarm to notify } \\
\text { the problem. }\end{array}$ & $\begin{array}{l}\text { Applied new } \\
\text { technology and } \\
\text { decreased } \\
\text { consumption. Also } \\
\text { depending on } \\
\text { aumento, application } \\
\text { that has cables plan- } \\
\text { controlling system } \\
\text { with an alarm to notify } \\
\text { the problem. }\end{array}$ \\
\hline $\begin{array}{l}\text { Social sustainable } \\
\text { spaces }\end{array}$ & Increased by time plan & Increased by time plan & Increased by time plan \\
\hline $\begin{array}{l}\text { The type of applied } \\
\text { maintenance }\end{array}$ & $\begin{array}{l}\text { Selection of the } \\
\text { maintenance strategy } \\
80 \% \text { Emergency and } \\
20 \% \text { preventive }\end{array}$ & $\begin{array}{l}\text { Selection of the } \\
\text { maintenance strategy } \\
80 \% \text { Emergency and } \\
20 \% \text { preventive }\end{array}$ & $\begin{array}{l}\text { Selection of the } \\
\text { maintenance strategy } \\
80 \% \text { Emergency and } \\
20 \% \text { preventive }\end{array}$ \\
\hline
\end{tabular}




\begin{tabular}{|c|c|c|c|}
\hline $\begin{array}{l}\text { The } \\
\text { sustainability } \\
\text { impacts over the } \\
\text { existing } \\
\text { maintenance risk } \\
\text { management }\end{array}$ & $\begin{array}{l}\text { Al- Ahly Club } \\
\text { Gezira Branch }\end{array}$ & $\begin{array}{c}\text { Al- Ahly Club } \\
\text { Al Sheikh Zayed } \\
\text { Branch }\end{array}$ & $\begin{array}{l}\text { Al- Ahly Club } \\
\text { Nasr City Branch }\end{array}$ \\
\hline $\begin{array}{l}\text { Water } \\
\text { management }\end{array}$ & $\begin{array}{l}\text { Using water } \\
\text { management system } \\
\text { reflects the water } \\
\text { consumption. } \\
\text { The highest number of } \\
\text { the water consumption } \\
\text { shown in this branch. }\end{array}$ & $\begin{array}{l}\text { Using water } \\
\text { management system } \\
\text { reflects the water } \\
\text { consumption. }\end{array}$ & $\begin{array}{l}\text { Using water } \\
\text { management system } \\
\text { reflects the water } \\
\text { consumption. }\end{array}$ \\
\hline $\begin{array}{l}\text { Electricity } \\
\text { Management }\end{array}$ & $\begin{array}{l}\text { Using aumento } \\
\text { Application that used to } \\
\text { control the electricity } \\
\text { cables }\end{array}$ & $\begin{array}{l}\text { Using aumento } \\
\text { Application that used } \\
\text { to control the } \\
\text { electricity cables }\end{array}$ & $\begin{array}{l}\text { Using aumento } \\
\text { Application that used } \\
\text { to control the } \\
\text { electricity cables }\end{array}$ \\
\hline $\begin{array}{l}\text { Materials } \\
\text { Management }\end{array}$ & $\begin{array}{l}\text { Using local construction } \\
\text { materials help to reduce } \\
\text { transportation distance } \\
\text { and costs, also if it } \\
\text { chosen wisely it will } \\
\text { help to save the costs for } \\
\text { long-term and works as } \\
\text { a passive design } \\
\text { element. }\end{array}$ & $\begin{array}{l}\text { Using local } \\
\text { construction materials } \\
\text { help to reduce } \\
\text { transportation distance } \\
\text { and costs, also if it } \\
\text { chosen wisely it will } \\
\text { help to save the costs } \\
\text { for long-term and } \\
\text { works as a passive } \\
\text { design element. }\end{array}$ & $\begin{array}{l}\text { Using local } \\
\text { construction materials } \\
\text { help to reduce } \\
\text { transportation distance } \\
\text { and costs, also if it } \\
\text { chosen wisely it will } \\
\text { help to save the costs } \\
\text { for long-term and } \\
\text { works as a passive } \\
\text { design element. }\end{array}$ \\
\hline Landscaping & $\begin{array}{l}\text { Using native vegetation } \\
\text { in the landscape }\end{array}$ & $\begin{array}{l}\text { Using native } \\
\text { vegetation in the } \\
\text { landscape }\end{array}$ & $\begin{array}{l}\text { Using native } \\
\text { vegetation in the } \\
\text { landscape }\end{array}$ \\
\hline $\begin{array}{l}\text { Building } \\
\text { Orientation }\end{array}$ & $\begin{array}{l}\text { The orientation of a } \\
\text { building has expanded } \\
\text { the energy efficiency } \\
\text { and thermal comfort } \\
\text { inside the building } \\
\text { areas. }\end{array}$ & $\begin{array}{l}\text { The orientation of a } \\
\text { building has expanded } \\
\text { the energy efficiency } \\
\text { and thermal comfort } \\
\text { inside the building } \\
\text { areas. }\end{array}$ & $\begin{array}{l}\text { The orientation of a } \\
\text { building has expanded } \\
\text { the energy efficiency } \\
\text { and thermal comfort } \\
\text { inside the building } \\
\text { areas. }\end{array}$ \\
\hline Spaces Planning & $\begin{array}{l}\text { Right order of the } \\
\text { spaces distribution } \\
\text { increase the thermal } \\
\text { comfort }\end{array}$ & $\begin{array}{l}\text { Right order of the } \\
\text { spaces distribution } \\
\text { increase the thermal } \\
\text { comfort }\end{array}$ & $\begin{array}{l}\text { Right order of the } \\
\text { spaces distribution } \\
\text { increase the thermal } \\
\text { comfort }\end{array}$ \\
\hline
\end{tabular}

Summary, the percentages of the sustainability impacts according to the existing operation of maintenance risk management of the selected sport clubs are,

$$
\text { - Water Management } \quad 60 \%
$$


- Electricity Management $\quad 50 \%$

- Materials Management $\quad 80 \%$

- Landscaping Management $\quad 60 \%$

- Building Orientation 40\%

- Spaces Planning Management 30\%

Figure 6, shows the percentages,

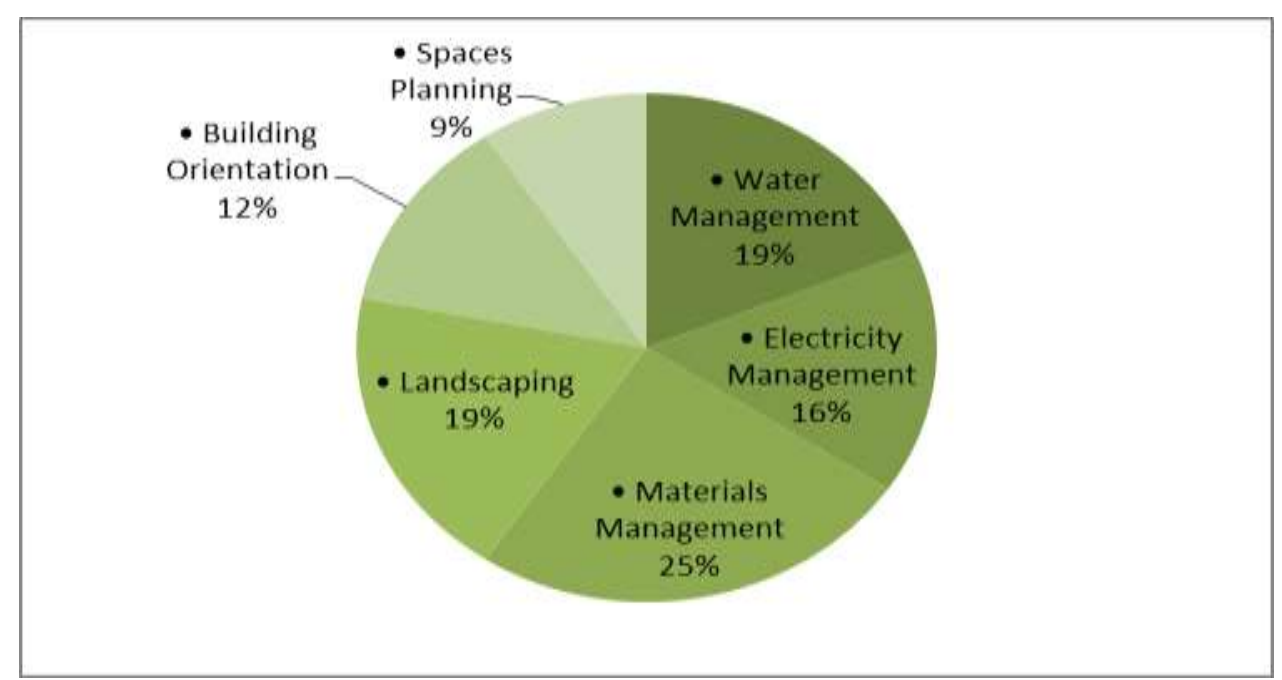

Fig. 6: showing the impact of the sustainability elements within different aspects in the selected sports club by author, (2020)

\section{SUMMARY AND CONCLUSIONS}

The research carried out a highlighted gap in the literature with the sustainable operation of construction of maintenance risk management as a method of delivering a sustainable longlasting and secure project. Furthermore, respondents showed that the absence of practical application and the availability of successful local examples is the primary reason for the failure to integrate safety and sustainability components in the construction of maintenance risk management in Egyptian sports clubs. This brings up an important point about the difference between the academic and practical parts of sustainability. In addition, respondents and the survey that have been done by the author clarify many points, the impact of the sustainability on the existing type of the applied operation of maintenance risk management strategy in the selected sports clubs showing on several categories:

In using new technologies to reduce the consumption of the use of water and electricity, increased the use of recycling materials, make continues training to the employees in order to sustain the employees and decreased the need to recruit new workers, improve the maintenance type, and maintain the existing tools and facilities continue to extend the life span. Besides that in order to make the safety and sustainability elements be much effective most to change the type of the applied operation of maintenance risk management into preventive maintenance risk management to increase the sustainability and safety impacts.

In addition, it's very important to encourage the governmental authorities to look up all the project types and setting the rules, establishing laws, and offering incentives to guarantee the integration of sustainability, risk management, and maintenance in the construction sector, in 
particular. In order to improve the long-term sustainability and safety of the project's life cycle and the industry as a whole.

\section{REFERENCES}

1. Aring, M. (2012), Skills Gaps Throughout the World: An Analysis for UNESCO Global Monitoring 2012, available at: http://unesdoc.unesco.org/images/0021/002178/217874e.pdf (accessed 31 August 2017).

2. Abdel-Basset, M.; Mohamed, R. A novel plithogenic TOPSIS-CRITIC model for sustainable supply chain risk management. J. Clean. Prod. 2020, 247, 119586.

3. Chiang, C.-T.; Kou, T.-C.; Koo, T.-L. A Systematic Literature Review of the ITBased Supply Chain Management System: Towards a Sustainable Supply Chain Management Model. Sustainability 2021, 13, 2547.

4. Gouda, S.K.; Saranga, H. Sustainable supply chains for supply chain sustainability: Impact of sustainability efforts on supply chain risk. Int. J. Prod. Res. 2018, 56, 58205835.

5. Jiang, X.; Lu, K.; Xia, B.; Liu, Y.; Cui, C. Identifying Significant Risks and Analyzing Risk Relationship for Construction PPP Projects in China Using Integrated FISMMICMAC Approach. Sustainability 2019, 11, 5206.

6. Kaur, M.; Singh, R. Risk and risk-handling strategies in construction projects. Int. J. Manage. Stud. 2018, 5, 1-7.

7. Michael Daragh Naughton, Peter Tiernan, (2012) "Individualising maintenance management: a proposed framework and case study", Journal of Quality in Maintenance Engineering, Vol. 18 Issue: 3, pp.267-281,

8. Mohamed Ben-Daya, Salih O. Duffuaa Abdul Raouf, Jezdimir Knezevic and Daoud AitKadi (2009) "Handbook of Maintenance Management and Engineering" Springer, London, UK.

9. Moktadir, M.A.; Dwivedi, A.; Khan, N.S.; Paul, S.K.; Khan, S.A.; Ahmed, S.;Sultana, R. Analysis of risk factors in sustainable supply chain management in an emerging economy of leather industry. J. Clean. Prod. 2021, 283, 124641.

10. Maduka, N., Greenwood, D., Osborne, A. \& Udeaja, C. (2016). Implementing Sustainable Construction Principles and Practices by Key Stakeholders. Modular and Offsite Construction Summit. 1-8.

11. Maxwell, S. (2014), Integrating Sustainability into the Engineering Design process Using the Global Reporting Initiative Indicators, available at: https://skemman.is/bitstream/1946/18543/1/Thesis\% 20June\%202014.pdf (accessed 31 August 2017).

12. Nawaz, A.; Waqar, A.; Shah, S.A.R.; Sajid, M.; Khalid, M.I. An innovative framework for risk management in construction projects in developing countries:

Evidence from Pakistan. Risks 2019, 7, 24.

13. Nimsai, S.; Yoopetch, C.; Lai, P. Mapping the Knowledge Base of Sustainable Supply Chain Management: A Bibliometric Literature Review. Sustainability 2020, 12, 7348.

14. Othman, A.A.E. and Abdelwahab, N.M. (2016), "A field study investigating the role of integrating risk management into the architectural design process as an approach towards delivering sustainable construction projects", Proceedings of the 10th Built Environment Conference, Port Elizabeth, 31 July - 2 August, pp. 261-272, ISBN number: 978-0-620-71904-9. 
15. Peter Muchiri, Liliane Pintelon, Ludo Gelders and Harry Martin, (2011) "Development of maintenance function performance measurement framework and indicators", International Journal of Production Economics, Volume 131, pp 295 302.

16. Property rights of the Central Agency for Public Mobilization and Statistics, 2020.

17. Ravi Kumar Goyal and Kapil Maheshwari, (2012), "Maintenance Management Practices: a retrospective and literature review", Journal of Advainces in Engineering Research, Volume3, issue 2.

18. S. A. Brah \& W.-K. Chong (2004) Relationship between total productive maintenance and performance, International Journal of Production Research, volume 42 Issue No.12, pp 2383-2401.

19. Sánchez, M.A. (2015). Integrating sustainability issues into project management. Journal of Cleaner Production, 96, 319-330.

20. Swanson L. (2001) Linking maintenance strategies to performance. International Journal of Production Economics, vol. 70, no 3, pp. 237-244.

21. Umar Al-Turki, (2011) "A framework for strategic planning in maintenance: methodology and theory", Journal of Quality in Maintenance Engineering Vol. 17 No. 2, pp. 150-162.

22. Waeyenbergh, G. and Pintelon, L. (2002) A framework for maintenance concept development. International Journal of Production Economics, vol. 77, no 3, pp. 299313.

23. Wenyan, S.; Xinguo, M.; Hu-Chen, L. Identifying critical risk factors of sustainable supply chain management: A rough strength-relation analysis method. J. Clean. Prod. 2017, 143, 100-115.

24. Shin, M.K.; Jo, W.J.; Cha, H.M.; Lee, S.H. A study on the condition based maintenance evaluation system of smart plant device using convolutional neural network. J. Mech. Sci. Tech. 2020, 34, 2507-2514.

25. Khan, F.I., \& Haddara, M. R. (2003). Risk-based maintenance (RBM): A quantitative approach for maintenance/ inspection scheduling and planning. Journal of Loss Prevention in the Process Industries, 16, 516-73. 